\title{
Floristic Diversity of Atriplexaies in Western Algeria
}

\author{
Kerzabi Rachida, Abdessamad Merzouk and Stambouli-Meziane Hassiba
}

Laboratory of Ecology and Management of Natural Ecosystems, Department of Biology, Faculty of Sciences, University Abou Bekr Belkaid Tlemcen, BP 119, 13000, Algeria

http://dx.doi.org/10.13005/bbra/2095

(Received: 20 February 2016; accepted: 11 April 2016)

\begin{abstract}
This Work is applied to study of evolution of vegetal to Atriplex of two different areas, the North and South of Western Algeria. This area presents a remarkable biodiversity by the vegetal halophiles habitations. The vegetal, in manner of general Tlemcen region, see its surface; this is for great part to human and climat action. The knowledge of particularly biologic and ecologic of these halophytes species in general is in all action of biodiversity. Ghezlaoui and al, 2009. The bioclimatic done in evidence to region study level, two types of climat, a climat for North area (Zenata, ES-Sénia) and a climat for south area (Mecheria, Naama and Ain-sefra). We effect 50 floristic lists in each station to complete lists of halophytes species wich are in study's area. Vegetal covert is dominated by therophytes, then chamaephytes and phanerophytes in last position. This general manner, the floor of soils always poor and characterized by special species and it's the chenopodiaceae family Ozenda, 1958.
\end{abstract}

Key words: Biodiversity, Atriplex halimus, salinity, Western Algeria, desertification, Climat.

The Mediterranean land scapes offer a study model of evolution of the vegetation. The variability of these even their differences kept very remarkable Quezel, 2000.

The great diversity of milieu of Mediterranean is the result of factors paleoclimatic, geomorphologic, ecologic specially anthropozoogène.

The Atriplex is a halophyte to Chenopodiaceae or Aramanthaceae regroups 1400 species. Atriplex genre contains near 417 on Mediterranean. Le Houerou, 1992. Plains of Atriplex genre locate in almost regions of globe, Kinet et al, 1998. We find then is Alaska, in Britain, in Norway, in Siberia and in South Africa. Franclet et Le Houerou, 1971. These halophyte species are much diversified, they relied plans of sea, beaches and certain plain of regions. Favrie and al, 2006.

Generally, it is associated to soils and to

* To whom all correspondence should be addressed. milieu, desertic or semi-desertic Rosas, 1989; ParSmith, 1982. It contains plains of herbaceous perennial and rarely, trees. They present adaptations xerophytic Mulas and al, 2004.

The halomorphes lands contain all parties of world especially Mediterranean region. Theys are in Maghreb.

Every year, surfaces are loosed from pollution. 20 millions has in the world. Thus, these surface are passed 48 million to 265 million ha of agricultural soil touched by pollution, agricultural surfaces which are effected in the world will be 340 million ha, its $23 \%$ of uses soil in the world Cheverry, 1995. Even Szablocs, 1994, milliards ha are menaced, 3.2 million ha in Algeria Belkhoudja and Bidai, 2004.

In Algeria, Atriplexes represent near million hectares more or less. Ouadah, 1982 and in steppe area, in sebkhas Froent, 1972.

Atriplex consist an important reserve. And heave great quantities of salt in their tissues, situated in surface Mozafar and goodin, 1970. Species of Atriplex are used in habitation of 
difficulty of the sites. They take out a very developed system fixed the superior coaches of sol witch can be used as a method of luted against desertification Belkhodja and Bidai, 2004.

A lot floristic studies are effected in cadre of knowledge about occupied media by the halophytes taxon specially Atriplexes, we can cite the from : Djebaili, 1984 ; le Houerou,1981; Benchaabane, 1997 ; Benabadji and al, 2004 ; Ghezlaoui, 2010 ; Merzouk, 2010 ; Aboura, 2011.

The climate change, in general be more and more opposite and the vegetal species development on their milieu.

\section{MATERIELSANDMETHODS}

\section{Geographic situation of study area}

The study area is localized in Western Algeria. The study environment is shared between the northern provinces of Tlemcen, Ain Temouchent and south between the Wilaya of Tlemcen and Naama. The study area is established between the latitudes of $33^{\circ}$ and $35^{\circ} 49^{\prime}$ North and Longitudes of $1^{\circ} 30^{\prime}$ and $0^{\circ} 30^{\prime}$ west.Geographically, our area is found naturally in two regions (Fig. 1).

Region 1: it is situated between Traras Mountains of Western-North and Djebel
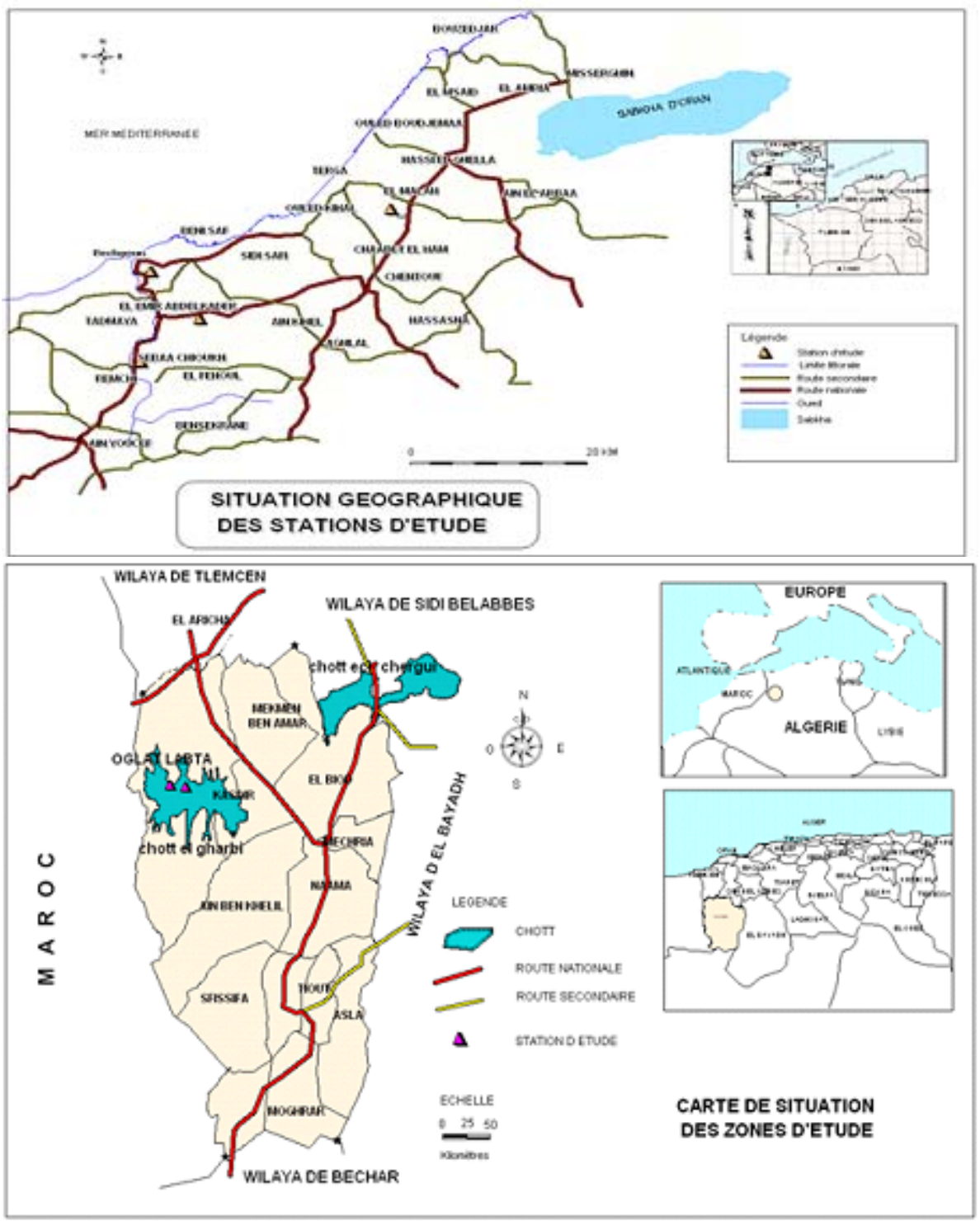

Fig. 1. Geographic situation of study stations (North and South) 


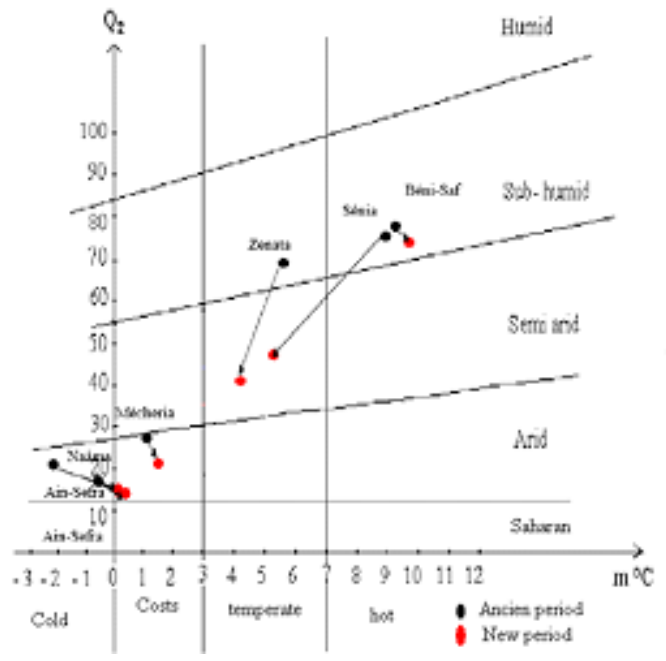

Fig. 2. Diagram pluviothermic of Emberger (Q2)

Murdjadjo of Eastern-North and between Tlemcen mountains of western-South and Tessala Mountains of Eastern-South.

Region2: it is part of high steppe plains; precisely the region of Chott-EL-Gharbi, witches open in North of Tlemcen Mountains (Djebel El Abed and Djebel Mekaidou). It's limited in south by atlas Saharan formed by Djebel El Arar, Djebel Kerrouch and Djebel Bou-Amoud.

The station choice is quite by vegetal diversity of halophytes groupements and Atriplex presence which makes object of our study plus ecologic factors of influence.

\section{Bioclimat}

The climate weight in ecosystem studies is very important, because it is an ecologic factor and element in other milieu Factors.

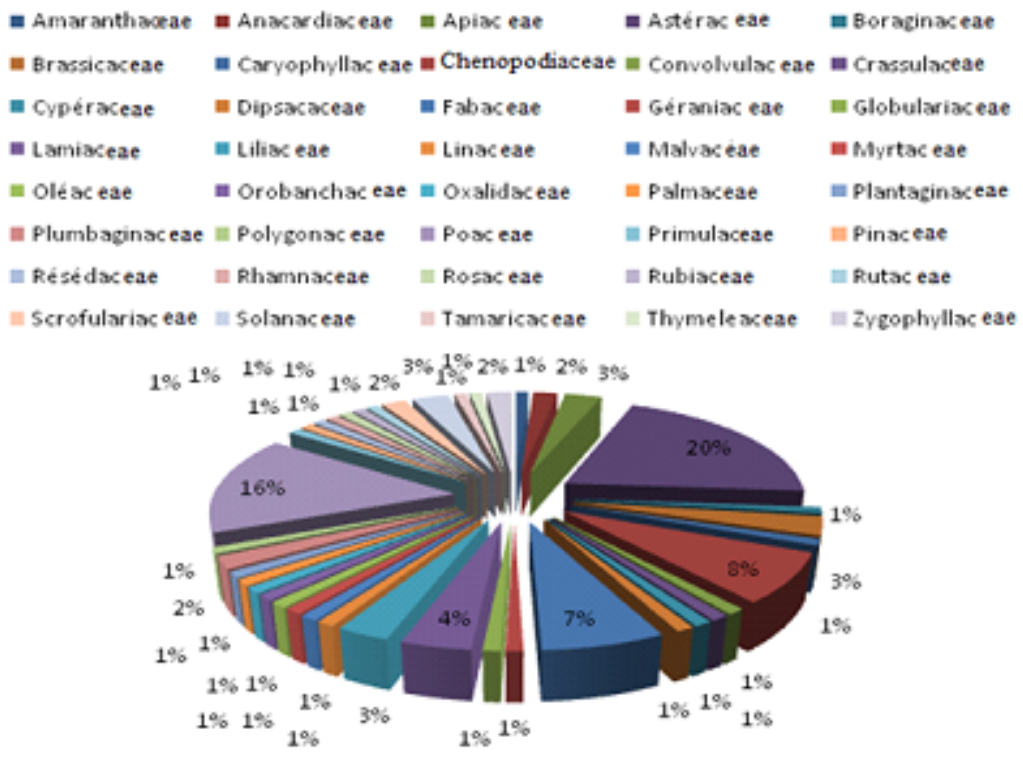

Fig 3. The study Area Families’ Percentage

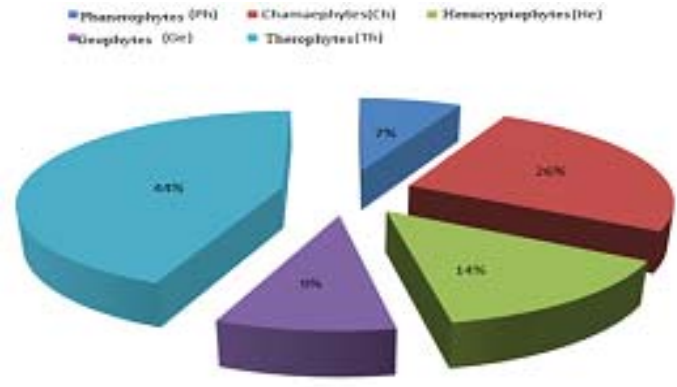

Fig. 4. Percentage of Biologic types of the study area

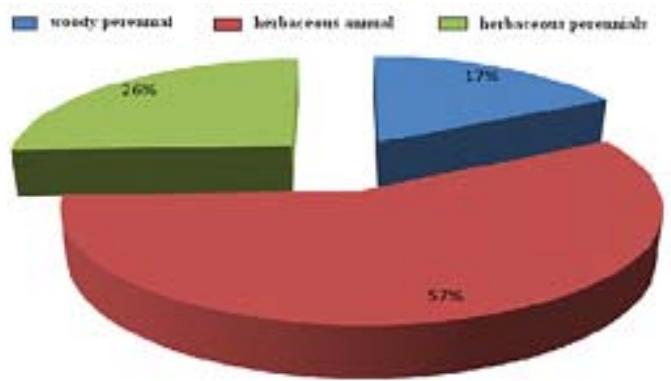

Fig. 5. Percentage of Morphologic types of the study area 
The Western Algerian climate has a Mediterranean climate characterized by quite winters, the hot summers and soft periods of autumn and spring.

We are explored the precipitation and temperature marks on six stations for make relief between an old period (1913-1938) and new period (1985-2010). This, permit us to calculated the Q2 to position stations of bioclimatic stages of Climagramme.

The pluviothermic climmagramme reading says that it existes a difference between stations situated in the North area and which situated in the South area, these later are in bioclimatic stage superior or inferior and that of North area at superior or inferior stage.

The diminution of value of Q2 between the two periods of bioclimatic stages:

* The Zenata's station of inferior sub-humid in winter to semi-arid inferior in winter.

* The Beni-Saf's station is situated in subhumid inferior stage of hot winter we notice a slight delay)

* The Es-Sénia 's station of sub- humid stage of hot winter to the semi-arid superior

* The Naama's station of superior arid cold winter to inferior arid cold winter

* The Ain-Sefra's station witch situated in inferior arid stage of cold winter.

* The Mécheria's station of semi-arid lower floor fresh winter to the dry than fresh winter.

Hot variant influences the coastline, temperate variant covers sub-coastal areas.
For Franclet and le Houerou(1971), Atriplex halimus is Nearly found in all bioclimatic stage, Mediterranean stage, sub-humid, humid, arid, semi-arid, superior and inferior Saharan.

\section{Floristic sampling -Method}

For good floristic procession, we use transects methods which consists a milieu to study under the right line. It's enough to tender a cord around 100 meters, it's devised into elementary unities, and we note species which are situated under the cords or around a sector of long of it for example $1 \mathrm{~m}$ of part or other.

The surveys were conducted in the spring season considered favorable for vegetative push, identified by 50 stations, each of these statements includes ecological characters stational order identified or measured on field: Localization of geographic station, topographic (slope, exposition), altitude, substratum, recouvrement, physiognomic of vegetation.

The use of this methodological approach will allow the development of floristic tables for each station.

\section{Results and interpretation Systematic Analyze}

According to floristic lists which are affected in different stations, the study area takes 40 families; 99 genres and 121 species.

Gymnosperms constitute $0.84 \%$ of the study area unlike angiosperms which dominate with 19.32\% and 79.83\% of Monocots and Eudicots..

The distribution of families in the study area is heterogeneous, the most important of the generic and specific level families are: Asteraceae

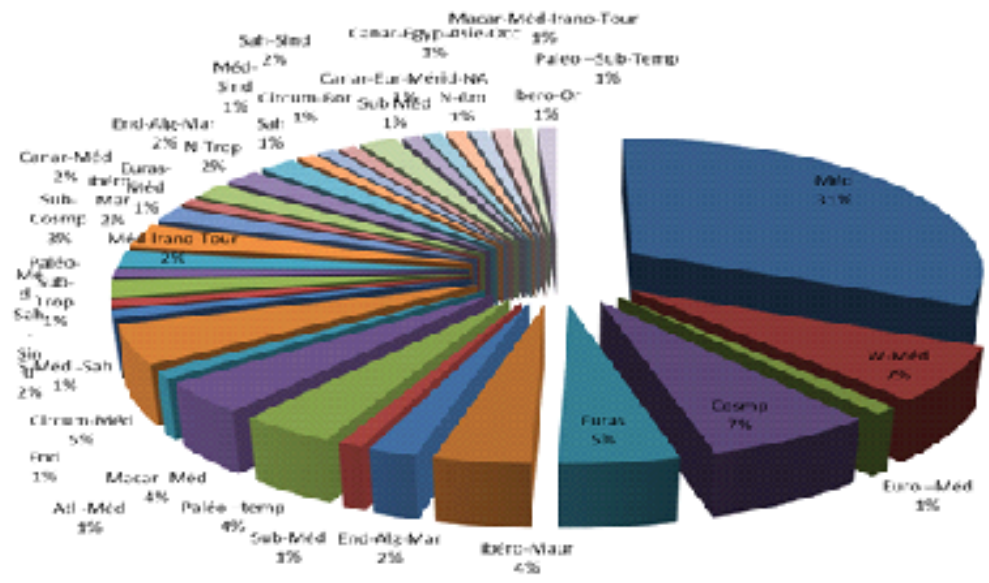

Fig. 6. Percentage of Biogeographically types of the study area 
(21), Poaceae (16), Chenopodiaceae (8), the Fabaceae (7) Lamiaceae (4), the Apiaceae, Brassicaceae a (3). The other families have a low percentage of very low and are generally mono generic and sometimes the same mono specific.

2 Biologic types Analyze:

As the biological types are conditioned by environmental factors, it is the dominance of either allowing naming the plant formation. One of these is that the physiognomic expression reflects the environmental conditions.

The counting of species biological types is performed on all species inventoried in each station.

From the results, the distribution of biological types of the vegetation between stations remains very heterogeneous..

* Remchi's station : presents the type $\mathrm{TH}>\mathrm{CH}>\mathrm{PH}>\mathrm{GE}>\mathrm{HE}$

* Rechgoun's station : presents the type $\mathrm{TH}>\mathrm{CH}>\mathrm{PH}>\mathrm{GE}>\mathrm{HE}$

* Amir Abdelkader's station : presents the type $\mathrm{TH}>\mathrm{CH}>\mathrm{HE}>\mathrm{PH}>\mathrm{GE}$

* El Maleh's station : presents the type $\mathrm{TH}>\mathrm{HE}>\mathrm{PH}>\mathrm{CH}>\mathrm{GE}$

* El Kasdir's station : presents the type $\mathrm{CH}>\mathrm{TH}>\mathrm{GE}>\mathrm{HE}>\mathrm{PH}$

* Oglat Labta's station : presents the type $\mathrm{TH}>\mathrm{CH}>\mathrm{HE}>\mathrm{GE}>\mathrm{PH}$

The composition of the spectrum of the study area shows a predominance of Therophytes with a percentage of $44 \%$ and is generally the most dominant in all stations (North zone).

Daget, 1980 and Barbero et al 1990 agree to present the theophyty as a drought-resistant form as well as high temperature in arid environments. The meaning of therophyty has been extensively debated by these authors attribute: either to adapt to the stress of the winter cold or summer drought, or disturbance of the environment by grazing and crops.

In the second position chamaephytes, with a percentage of $31 \%$.For the two stations in the southern zone is the chamaephytes dominate with a share over $50 \%$

According Benabadji et al. 1995; grazing promotes the installation of a comprehensive manner chamaephytes often rejected by the herd.

After Hemicryptophyte which are very little represented with a percentage of $14 \%$ witch permits' to explain the poverty of organic manner of sol.

Then Geophytes come are less represented with a percentage of $9 \%$ liliaceae as example: Aspargus acutifolus, Asphodelus microcarpus, urginea maritima.

Finally phanerophytes are less per presented by percentage of $7 \%$, which are dominated by their biomass especially in the North area (Rechgoun and EL Maleh) in the bed of Oued, and total absence in EL Kasdir station.

\section{Morphologic analyze}

Morphologic point of view, vegetal formation of study area is marked by heterogeneity between ligneous and herbaceous, and between perennial and annuals.

Herbaceous annuals are dominating with a percentage of $75 \%$ herbaceous perennial $26 \%$ in two positions, after the perennial ligneous with $17 \%$.

The strong degradation around regeneration of species, the most no-regeneration of perennial train then the modification which give parkours no resilient and train also the changement in the potential production and the botanic composition wilson,1986.

Structural instability of the soil ( sandy substrate ), the organic manner's poverty and climatic rigors favorite the installation and the development of species' short life cycle in depend of ligneous generally plus exigent of hydric and trophic needs.

In other part, we exigent that annual herb demands under perennial herbs .these results are also confirmed by a lot researcher around the floor and the vegetation of Tlemcen.

\section{Phyto-geographical analysis}

Quezel, 1983, explains this important biogeography diversity of Mediterranean Africa by climatic modifications suffered in this region since the Miocene which trains the migrations of tropical flora. On the phytogeographic map, the vegetation of the study area consists of a heterogeneous set of elements of various northern and southern Mediterranean origins.

The distribution of taxon inventoried is determined from the flora of Algeria, Quezel and Santa 1962-1963 and flora of France Gaston Bonnier, 1990

Phytogéographical analyze appears the 
species predominance of biogeography of Mediterranean type (Med) in study area which are the most abundant with percentage of 31\% (33 species), following the Western Mediterranean elements (W.Med) and cosmopolite (Cosmp) wiyh percentage of $7 \%$ (represented by 7 species).

Eurasiatic (Euras) and Circummediteranien (Circum-Med) elements be in third position with $5 \%$ species. The ibero Mauritanien (Ibro-Maur) elements and paleo Temperate (Paleotemp) is a percentage of $4 \%$ and the Sub Cosmopolite element with a percentage of $3 \%$.

\section{CONCLUSION}

The halophyte vegetation which is from Mediterranean vegetation is exposed to a dynamic which operates the interaction of ecologic multitude factors.

The continual of vegetal structure changement in region level of Western Algerian (Oran), results a conjugate action of human and climate

The Atriplex halimus is the species of salt steppe formation can only meet in the highlands and along the coast where favorable conditions exist with sometimes different polymorphisms. In this steppe vegetation on the physiognomy plain forms a fringe of a very variable larger around salt depressions.

Le Houerou, 2000, is noted that Atriplexes have enough armed characteristics against the desertification, all contain a minimum productive level of aliments for battle and sometimes permits' the superior revenues to traditional forages systems.

The climate is considered as the first factor which can influence directly, during the dries periods about certain milieus which provoke a high concentration on seal by evaporation given this a halomorphe soil.

The bioclimatic study appears that the pluviometric gradient decreases from North to South that influences onto floristic composition of Atriplexes. Certain tendency to aridity of the climate with longer drought period for the southern zone of 8 to 9 months in relation to the North Zone which lasts from 6 to 7 months.

The sorts of denombrement biologic types of study area accuses the therophytes predominance with percentage of $44 \%$, then the Chamaephytes with a percentage of $31 \%$ and the phanerophytes in last position with a percentage of $7 \%$ that are dominants' by its biomass specially in the North area.

Over the phytogeographical plan, the vegetation of study area appears a predominance species of Mediterranean types on other types of distribution with a percentage of $31 \%$.

Ghezlaoui and al, 2009 are concluding that the floristic procession of the south region of Oran (Chott EL gharbi) is remarked by a poverty compared to the North. This arid ecosystem is characterized by very presence locality of xerophytes steppe vegetal settlements and often exposed to irreversible degradation.

\section{REFERENCES}

1. Aboura R., Contribution à l'étude des Atriplexaies en Algérie occidentale. Aspects physionomiques et phytodynamiques. Thèse. Doct .ecol Vég. Univ.Tlemcen 2011; 156

2. Barbero M., Quezel P. et Loisel R., Les apports de la phytoécologie dans l'interprétation des changements et perturbations induits par l'homme sur les écosystèmes forestiers méditerranéens. Forêt Méditerranéenne. 1990; : 194-215.

3. Belkhodja M., Bidai Y., Réponse de la germination des graines d'Atriplex halimus L. sous stress salin. Revue Sécheresse, $N^{\circ} 4$, 2004; 15: 331-335.

4. Benabadji N., Etude phytoécologique de la steppe à Artemisia herba-alba Asso.Et à Salsola vermiculata L. au Sud de Sebdou (Oranie, Algérie). Thèse. Doct. Es-Sc. Univ.Tlemcen. 153 p + 150 p annexes, 1995.

5. Benabadji N., et Bouazza M., Quelques modifications climatiques intervenues dans la Sud-Ouest de l'Oranie (Algérie occidentale) Rev Energ.Ren.2000; 3: 117.125

6. Benabadji N., Bouazza M., Merzouk M., et Ghezlaoui B., - Aspects phytoécologiques des Atriplexaies au Nord de Tlemcen (Oranie, Algérie). Rev. Sci et Tech. $\mathrm{N}^{\circ} 22$. Constantine. 2004; 62-79

7. Benchâabane A., Biotechnologie et sécurité alimentaire. Cas de l’Atriplex halimus L. dans la production de viande de camelins et de caprins dans la vallée du Drâa (Maroc) dans : Actualité Scientifique : Biotechnologie, Amélioration des Plantes et Sécurité Alimentaire. Collection 
Universités Francophones. Ed. ESTEM, Paris, 1997; 169.

8. Cheverry C., Plant behaviour in saline environnement. Action eau ; $n^{\circ} 4$, Séance spécialisée du 22 mars 1995 ; Ed. Acad. agro,Paris, France, 1995; 49.

9. Daget PH., Sur les types biologiques botaniques en tant que stratégie adaptative, cas des thérophytes. In « Recherches d'écologie théorique ». Les stratégies adaptatives. 1980; 89-114.

10. Djebaili S., Steppe algérienne, phytosociologie et écologie. O.P.U. Alger. 1984; 171.

11. Favrie C., Ferra C., Medori P., Devaux J., Hemptinne J.L., Ecologie : approche scientifique et pratique. 5é éd. Tec et Doc.2006; 407p.

12. Franclet A. et Le Houérou H.N., Les Atriplex en Tunisie et en Afrique du Nord. Doct. F.A.O. Rome 1971; 249 et p 189

13. Froment D., Etablissement des cultures fourragères d'Atriplex en Tunisie centrale in « Sém. Et. Prob. Méd. , 1972 .

14. Gaston B., La grande flore en couleurs (la flore de France).Edit. Belin. Tome I, II, III, IV, Index. Paris. France, 1990.

15. Ghezlaoui B., Benabadji N., AbouraR., Approche floristique et physionomique des Atriplexaies au nord de Tlemcen. (Ouest Algérie). Rev mediterranea $\mathrm{N}^{\circ} 20$ serie de estidios biologicos epoca II univ Alicante 2009; 12.

16. Ghezlaoui B., Bio-morphologie et polymorphisme des appareils aériens de quelques espèces halophytes en Oranie, cas de Atriplex halimus Let tamarix gallica). These. Doc. Ecol. Vég. Univ. Tlemcen, 2010.

17. Kinet J.M., Benrebiha F., Bouzid S., Lailhacar S. et Dutuit P., Le réseau Atriplex, Allier biotechnologies et écologie pour une sécurité alimentaire accrue en régions arides et semiarides. Cah. Agr. 1998 ; 7(6): 505-509.

18. Le Houérou H.N., The feed value of Atriplex ssp. Techn. Paper. $\mathrm{N}^{\circ}$ 13. UNTF/ Lib 18, FAO and Agric. Res, Cent, Tripoli. Lybia. 1981; 5.

19. Le Houérou H. N., The role of saltbushes (Atriplex spp.) in arid land rehabilitation in the Osmond C.B., Bjorkman O., et Anderson D.J., 1980 - physiological process in plant ecology. Toward a semi-arid lands. Ed. Academic press. INC, New York (U.S.A), 1992; 601-642

20. Le Houérou H. N., Utilization of fodder trees and shrubs in the arid and semi arid zones of west Asia and North Africa. Arid Soil Research Rehabilitation, 2000; 14: 101-135.

21. Merzouk A., Contribution à l'étude phytoécologique et bio morphologique des peuplements végétaux halophiles de la région de l’Oranie (Algérie). Thèse. Doc. Ecol. Univ. Tlemcen. 2010; 261.

22. Mozafar, A., Goodin, J.R., Vesiculated hairs: a mechanism for salt tolerance in $\mathrm{A} \mathrm{t} \mathrm{r}$ i $\mathrm{p} \mathrm{l}$ e $\mathrm{x}$ halimus L. Plant Physiol. 1970; 45: 62 et 65.

23. Mulas.M et Mulas G., Potentialités d'utilisation stratégique des plantes des genres Atriplex et Opuntia dans la lutte contre la désertification. SMap.2004; 112p.

24. Ouadah Y., Contribution à l'étude des principales essences d'intérêt fourrager des régions arides et semi-arides d'Algérie : Application à quelques espèces. Mém. Ing.I.N.A. 1982 ; 108p.

25. Ozenda P., Flore du Sahara Septentrional et central. Par-Smith G.A., 1982_ Biogeography and evaluation of the shrubby Australian species of Atriplex. In:W.R.Barker and P.J Greensdale (eds). Evolution of the flora and Fauna of arid Australia. Peacock, Freeville, S. Australia. 1958; 221-299.

26. Quezel P., et Santa S., Nouvelle flore de l’Algérie et des régions désertiques méridionales. Paris C.N.R.S. 2 1962- 1963; 1170 p.

27. Quezel P., Flore et végétation de l’Afrique du Nord, leur signification en fonction de l'origine, de l'évolution et des migrations des flores et structures de végétations passées. Bothalia, 1983; 14: 411-416

28. Quezel P., Réflexions sur l'évolution de la flore et de la végétation au Maghreb méditerranéen. Ibis Press. Paris, 2000; 117.

29. Rosas M.R., El genero Atriplex (Chénopodiaceae) en chile. Gayana Bot. 1989; 382.

30. SZABOLCS I., oils and salinization. In: Pessaraki, M. (Ed.à,Handbook of plant and Crop Stress, Marcel DEKKE, New York1994; 3-11.

31. Tafer B., Etude phytoécologique et syndynamique des complexes de végétation halophile de la plaine de Mohammadia (MactaOranie).Thèse. Doc .Aix Marseille III. 1993; 68117

32. Wilson A.D., Principals of gazing management system in regelands under siege (proc-2d, international regeland congress- Adelaide, 1984), 221-225 Australian acab. Sic-canberra, 1986. 